\title{
REKAYASA TEKNIK SIPIL
}

Media Publikasi Karya Ilmiah di Bidang Teknik Sipil

Volume 5, Nomer 1.

Juni 2020

\section{DAFTAR ISI}

1. Analisis Kepuasan Penumpang Kereta Api Terhadap Angkutan Umum di Stasiun Madiun

Arinda Leliana, Blima Oktaviastuti

2. Pengaruh Bahan Tambah Serbuk Ban Bekas Pada Konstruksi Hotrolled Sheet-Wearing Course

Blima Oktaviastuti, Arinda Leliana, Luthfil Abid

3. Evaluasi Kinerja Sistem Manajemen Keselamatan dan Kesehatan Kerja (SMK3) Pada Proyek Attic Showroom dan East Coast Center 2 Di Surabaya

Juliandres Unitly, Feri Hariant, Diah Listyaningsih

4. Pengaruh Penerapan Keselamatan Dan Kesehatan Kerja (K3) Serta Lingkungan Kerja Terhadap Produktivitas Kerja Di Surabaya Ahmad Zainul Arifin ,Feri Harianto

5. Analisa Kualitas Pekerjaan Dinding Dengan Bata Merah dan Bata Ringan (Studi Kasus : Perumahan Type 46 Di Kabupaten Pamekasan)

Dedy Asmaroni ,Ach. Rofii 